\title{
Evaluation of antimicrobial, cytotoxic and chemopreventive activities of carvone and its derivatives
}

\author{
Isabela Jacob Moro ${ }^{1 *}$, Gabrielle Demmany Gualberto Alexandre Gondo ${ }^{1}$, Elaíse Gonçalves Pierri ${ }^{1}$, \\ Rosemeire Cristina Linharis Rodrigues Pietro ${ }^{2}$, Christiane Pienna Soares ${ }^{3}$, Damião Pergentino de \\ Sousa $^{4}$, André Gonzaga dos Santos ${ }^{1}$
}

\begin{abstract}
${ }^{1}$ Laboratory of Pharmacognosy, School of Pharmaceutical Sciences, São Paulo State University (Unesp), Araraquara, ${ }^{2}$ Laboratory of Biotechnology, School of Pharmaceutical Sciences, São Paulo State University (Unesp), Araraquara, ${ }^{3}$ Laboratory of Cell Biology, School of Pharmaceutical Sciences, São Paulo State University (Unesp), Araraquara, ${ }^{4}$ Departament of Pharmaceutical Sciences, Health Sciences Center, UFPB - Univ Federal da Paraiba
\end{abstract}

\begin{abstract}
Considering the reported activity of carvone in the literature, this study aimed to evaluate the antimicrobial, cytotoxic and chemopreventive activities of $(+)$ - and (-)-carvone, $(+)$ - and (-)- hydroxydihydrocarvone and $\alpha, \beta$-epoxycarvone. (+)-Hydroxydihydrocarvone $(\mathrm{HC}+),(-)$-hydroxydihydrocarvone $(\mathrm{HC}-)$ and $\alpha, \beta$ epoxycarvone (EP) were obtained by synthesis using $(+)$-carvone $(\mathrm{C}+)$ or $(-)$-carvone $(\mathrm{C}-)$ as precursors. The antifungal activity (MIC and MFC) were evaluated against Candida parapsilosis, C. tropicalis, C. krusei and C. albicans and the antibacterial activity (MIC and MBC) against Escherichia coli and Staphylococcus aureus. The cytotoxicity assays were performed with human cancer cell lines HepG2 and $\mathrm{SiHa}$ and the normal strain MRC-5 through sulphorrodamine B assay. Chemoprevention was evaluated through quinone reductase assay. Our results showed no cytotoxicity on tumor and normal cell lines and no induction of the quinone reductase enzyme. C- and HC-presented activity against $E$. coli. All compounds presented weak antifungal activity against $C$. tropicalis and C. parapsilosis. EP and $\mathrm{C}+$ showed moderate activity against $C$. krusei. Results suggest the potential use of carvones and its derivatives as antifungal agents against Candida yeasts. The absence of cytotoxicity in cell lines indicates safety in the use of these compounds.
\end{abstract}

Keywords: Carvone/antimicrobial activity. Carvone/antifungal activity. Carvone/cytotoxicity. Carvone/ chemoprevention.

\section{INTRODUCTION}

Natural products diversity is an important source in the search for bioactive compounds. Plants have a wide range of secondary metabolites that are important for the discovery of drugs for various diseases such as cancer and infections by microorganisms. Essential oils are generally a mixture of secondary metabolites including terpenes and phenolic compounds, mainly monoterpenes, sesquiterpenes, phenylpropanoids and other low molecular weight volatile compounds. Essential oils are responsible for the characteristic odor of aromatic plants which is

\footnotetext{
*Correspondence: I. J. Moro. Laboratório de Farmacognosia, Faculdade de Ciências Farmacêuticas, UNESP, Univ Estadual Paulista, Rodovia Araraquara-Jaú, Km 01, n/n, Campus Ville, 14800-903, Araraquara - SP, Brasil. Tel: +55 16 3301-6993. E-mail: isabela.jm87@gmail.com
}

important for attracting pollinators and seed dispersers, moreover, it acts as a defense mechanism against predators and diseases. Many of them present pharmacological activity and may be used therapeutically (De Sousa, 2015; Bakkali et al., 2008; Wagner, Elmadfa, 2003). Carvone and related metabolites are monoterpene constituents of essential oils that presented interesting activities including antibacterial, antifungal, anticonvulsivant and cytotoxic to cancer cell lines (Carvalho, Fonseca, 2006; Chen et al., 2006; Freire; Costa, 2006; Stammati et al., 1999).

The enantiomers $(4 S)-(+)$-carvone and $(4 R)-(-)-$ carvone (Figures 1a and 1b) are monoterpenes found in essential oils from various plant species, commonly used in food and pharmaceutical products, such as Carum carvi L., Anethum graveolens L., Mentha spicata L. and Mentha viridis (L.) L. The carvone isomers or essential oils rich in carvone were effective against a wide spectrum of human 
pathogenic fungi (eg. Candida albicans) and bacteria (eg. Campylobacter jejuni and Listeria monocytogenes) (Carvalho, Fonseca, 2006; Mcgeady, Wansley, Logan, 2002; Rault et al., 2013). Zheng, Kenney and Lam (1992) demonstrated that carvone induced the detoxifying phase II enzyme glutathione $S$-transferase in several mouse target tissues, which shows the potential cancer chemopreventive action of the compound. Moreover, carvone inhibited viability and proliferation of Hep-2 cells (human carcinoma epithelial cells) probably inducing apoptosis without causing DNA damage (Stammati et al., 1999). De Sousa et al. (2007a) also demonstrated its depressant effects on central nervous system and the anticonvulsivant action of $(+)$-carvone. The monoterpene $\alpha, \beta$-epoxycarvone (Figure 1c) is an essential oils found in Carum carvi L. (Iacobillis et al., 2005), Catasetum maculatum Kunth. (Lindquist et al., 1985), Kaempferia galanga L. (Jirovetz et al., 2001) and other aromatic plants (Kaiser, 1997). This monoterpene presented antimicrobial activity against Candida albicans and Staphylococcus aureus (Arruda et al., 2006). Additionally, it showed anticonvulsant, antinociceptive, anti-inflammatory, antiulcerogenic and antioxidant activities (De Sousa et al., 2007b; De Almeida et al, 2008; Siqueira et al., 2012; Salgado et al., 2015). The semisynthetic compounds (+)-hydroxydihydrocarvone and (-)-hydroxydihydrocarvone (Figure $1 \mathrm{~d}$ and 1e) were obtained from hydration of (+)-carvone or (-)-carvone. The (-)-Hydroxydihydrocarvone demonstrated antinociceptive and anti-inflammatory activities along with depressant effects on central nervous system (De Sousa, Oliveira, Almeida, 2006; De Sousa et al., 2010; Oliveira et al., 2007; Oliveira et al., 2009). Regarding toxicological studies, data from literature indicates low toxicity of all these compounds (De Sousa et al., 2007a; De Sousa et al., 2007b; Oliveira et al., 2009); only (+)-hydroxydihydrocarvone have not been evaluated regarding its toxicological parameters.

Considering the reported activities of carvone in the literature, this study aimed to evaluate the antimicrobial, cytotoxic and chemopreventive activities of $(+)$ - and (-)-carvone, (+)- and (-)-hydroxydihydrocarvone and $\alpha, \beta$-epoxycarvone. Although enantiomers have similar physicochemical properties, they have different behavior in chiral environments, such as endogenous drug receptors, membrane proteins and enzymes. The antifungal activity was evaluated against Candida parapsilosis, Candida tropicalis, Candida krusei and Candida albicans and the antimicrobial activity against Escherichia coli and Staphylococcus aureus. The cytotoxicity assays were performed with human cancer cell lines HepG-2 (hepatocellular carcinoma) and $\mathrm{SiHa}$ (cervical tumor cell)

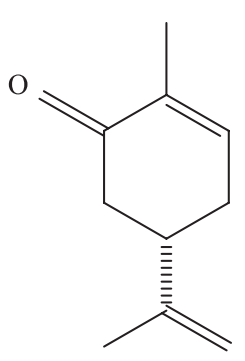

(A)

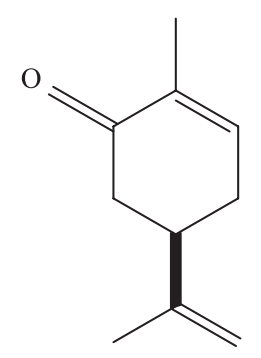

(B)

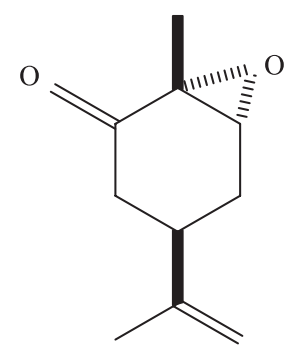

(C)

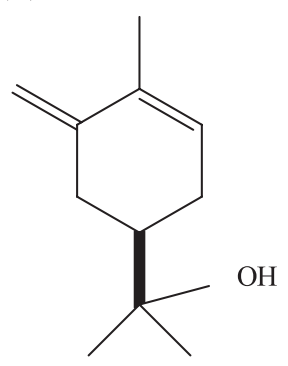

(D)

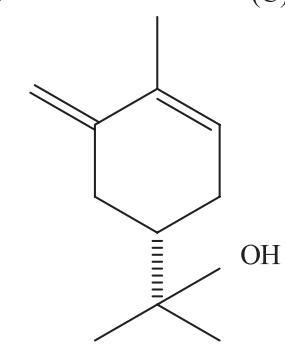

(E)
FIGURE 1 - Chemical structures of (a) $(4 S)-(+)$-carvone, (b) (4R)-(-)-carvone, (c) $\alpha, \beta$-epoxycarvone, (d) (-)-hydroxydihydrocarvone and (e) (+)-hydroxydihydrocarvone.

and normal strain MRC-5 (normal lung fibroblast) through sulphor rodamine B assay.

Regarding potential chemopreventive action, the compounds were also evaluated in the induction of quinone reductase assay. Cancer quimioprevention involves the use of natural or synthetic agents to prevent, reverse or retard the carcinogenesis process.

\section{MATERIAL AND METHODS}

\section{Compounds}

$(4 S)-(+)$-carvone and $(4 R)-(-)$-carvone $(\mathrm{C}$ - and $\mathrm{C}+)$ were purchased from Sigma-Aldrich ${ }^{\circledR}$. Derivatives (+)-hydroxydihydrocarvone and (-)-hydroxydihydrocarvone ( $\mathrm{HC}+$ and $\mathrm{HC}-)$ were obtained from hydration of $\mathrm{C}+$ and $\mathrm{C}$ - according to the method described by Bucho e Wuest (1979). The hydration was performed by reaction with $50 \%$ sulfuric acid, agitating in a magnetic stirrer for $40 \mathrm{~h}$ at room temperature. $\alpha, \beta$-Epoxy-carvone (EP) was prepared from C- according to Klein and Ohloff (1963).

\section{Preparation of test samples}

For antimicrobial testing the substances $\mathrm{C}+, \mathrm{C}$-, $\mathrm{H}+, \mathrm{H}-$ and $\mathrm{EP}$ were solubilized $(10.0 \mathrm{mg} / \mathrm{mL})$ in Tween 80 ( $1 \%$ in PBS). Carvones were tested at concentrations of $2.5,1.25,0.625,0.312,0.156,0.078,0.039$ and 0.019 
$\mathrm{mg} / \mathrm{mL}$. In the cytotoxicity and quinone reductase assays the concentrations of carvones were 50.0, 16.6, 5.5, 1.8 and $0.6 \mu \mathrm{g} / \mathrm{mL}$.

\section{Microorganisms}

Strains of bacteria and yeast used in this study were Bacillus subtilis (ATCC 9362), Staphylococcus aureus (ATCC 25923), Escherichia coli (ATCC 10536), Candida albicans (ATCC 64548), Candida parapsilosis (ATCC 22019), Candida tropicalis (ATCC 750), and Candida krusei (ATCC 6258). A bacterial colony of each strain was inoculated in brain heart infusion (BHI) broth and incubated at $37^{\circ} \mathrm{C}$ for $24 \mathrm{~h}$. The final concentration of cells in suspension was adjusted to $0.5 \mathrm{McF}$ arland standard (approximately $1.5 \times 10^{8}$ cells $/ \mathrm{mL}$ ). Yeast colonies were incubated for $48 \mathrm{~h}$ at $35{ }^{\circ} \mathrm{C}$ and suspended in $5 \mathrm{~mL}$ of $0.9 \%$ sterile saline solution. Yeast cells were counted in Neubauer chamber and adjusted to a final concentration of $2.5-5.0 \times 10^{3}$ cell $/ \mathrm{mL}$.

\section{Positive controls}

Ampicillin was used as positive control in antibacterial assays with stock solution concentration of $50 \mathrm{mg} / \mathrm{mL}$ (deionized water). Amphotericin B was used as a positive control for Candida strains with stock solution concentration of $32 \mathrm{mg} / \mathrm{mL}$ (dimethylsulfoxide: RPMI1640 medium $1: 5 ; \mathrm{v} / \mathrm{v})$.

\section{Determination of Minimum Inhibitory Concentration (MIC) by microplate dilution Method and Minimum Fungicidal Concentration (MFC)}

MIC was determined using microplate dilution assays according to reference document M27-A3 of the CLSI with modifications (CLSI, 2008). RPMI-1640 containing glutamine and phenol red was used in Candida strains maintenance, the medium, without sodium bicarbonate, was supplemented with 3-( $N$-morphin)propanesulfonic acid (MOPS) at $0.165 \mathrm{M}, \mathrm{pH}$ 7.0. In each well of a microplate, $100 \mu \mathrm{L}$ of sterilized RPMI-1640 medium was added. Then, $100 \mu \mathrm{L}$ of carvone samples were added to the first well of each column (columns 1-8). In the column $9,100 \mu \mathrm{L}$ of amphotericin B was added to the first well. Serial dilution was performed by transferring $100 \mu \mathrm{L}$ from the first to the next until the end of the line. Finally, $100 \mu \mathrm{L}$ of yeast was added to each well to a final concentration of $2.5 \times 10^{3}$ cells $/ \mathrm{mL}$. Controls: yeast growth control (medium and yeast), solvent control ( $100 \mu \mathrm{L}$ of $1 \%$
Tween 80 with and without yeast), sterility control (only medium), compound control (compound and medium) and positive control (amphotericin B). The microplates were incubated for $48 \mathrm{~h}$ at $35^{\circ} \mathrm{C}$ under agitation. Fungal growth inhibition was assessed by the addition of 20 $\mu \mathrm{L}$ of $2 \%$ aqueous solution 2,3,5-triphenyltetrazolium chloride (TTC) that was read after incubation at 35 ${ }^{\circ} \mathrm{C}$ for $1 \mathrm{~h}$. The lowest concentration which no visible growth was observed was considered the minimum inhibitory concentration (MIC). Tests were performed in triplicate. The minimal fungicidal concentration (MFC) was determined by plating the contents of each sample from MIC test into Petri dish containing Saboraund agar. The plates were incubated for $48 \mathrm{~h}$ at $35^{\circ} \mathrm{C}$. MFC was evaluated by absence or presence of yeast growth.

\section{Determination of Minimum Inhibitory Concentration (MIC) by microplate dilution method and Minimum Bactericidal Concentration (MBC)}

MIC was determined using dilution microplate method, according to reference document M7-A9 of the CLSI with modifications (CLSI, 2012). For that, $100 \mu \mathrm{L}$ of BHI (brain heart infusion) was added to the wells. Then, $100 \mu \mathrm{L}$ of carvone (or derivatives) sample was added to the first well of each column (columns 1-8). In the column $9,100 \mu \mathrm{L}$ of ampicillin was added in the first well. Serial dilution was performed transferring $100 \mu \mathrm{L}$ from the first well to the subsequent until the end of each line. Finally, $100 \mu \mathrm{L}$ of bacterial suspension $(1: 200 ; \mathrm{BHI})$ was added to each well. The final concentration of bacteria in each well was $2.5 \times 10^{5}$ cells $/ \mathrm{mL}$. Controls: solvent control (Tween $801 \%$ with and without bacteria), growth control (bacteria and medium), sterility control (only medium), compound control (compound and medium) and positive control (ampicillin). Microplates were incubated for $24 \mathrm{~h}$ at 37 ${ }^{\circ} \mathrm{C}$. The growth inhibition was detected by adding $20 \mu \mathrm{L}$ of a $0.01 \%$ aqueous solution of resazurin after incubation at $37{ }^{\circ} \mathrm{C}$ for $1 \mathrm{~h}$. Tests were performed in triplicate. The minimal bactericidal concentration (MBC) was determined by plating each sample of the MIC test into Petri dishes containing agar Mueller-Hinton. Petri dishes were incubated for $24 \mathrm{~h}$ at $37^{\circ} \mathrm{C}$. MBC was evaluated by absence or presence of bacterial growth.

\section{Cell lines and cell culture}

The cell lines used in cytotoxicity assays was HepG2 (human hepatocellular liver carcinoma, ATCC $\left.{ }^{\circledR} H B-8065^{\mathrm{TM}}\right)$, courtesy of Dra. Dayse Maria 
Favero Salvadori (Department of Patology, UNESP), $\mathrm{SiHa}$ (human cancer of cervix, ATCC®HB-35 ${ }^{\mathrm{TM}}$ ), courtesy of Dra. Luisa Lina Villa (Laboratory of Virology, Ludwig Institute) and MRC-5 (human lung fibroblast, ATCC $\left.{ }^{\circledR C C L}-171^{\mathrm{TM}}\right)$. In the quinone-reductase assay, the cell line used was Hepa c1c7 (murine hepatocellular carcinoma, ATCC $\left.{ }^{\circ} C R C-2026^{\mathrm{TM}}\right)$, courtesy of Dr. John M. Pezzuto of College of Pharmacy, University of Hawaii. The medium used for in vitro culture of HepG2, SiHa and MRC-5 was Dulbecco's Modified Eagle Medium (DMEM) and for Hepa c1c7 was Alfa Modification of Eagle Medium ( $\alpha$-MEM). DMEM and $\alpha$-MEM were supplemented with fetal bovine serum for cells maintenance. The cells were cultured in bottles at $5 \% \mathrm{CO}_{2}$ atmosphere and $37^{\circ} \mathrm{C}$ until the cell monolayer reached confluence (80\%). After, cells were washed with Hanks and trypsin-EDTA solutions to detach cells and counting.

\section{Sulforhodamine B (SRB) assay}

SRB is used to measure the protein content in adherent cell cultures using 96 wells microplate. The plates were pre-incubated with culture medium (DMEM supplemented with $10 \%$ fetal bovine serum, $100 \mu \mathrm{L} /$ well) for $24 \mathrm{~h}$ at $37{ }^{\circ} \mathrm{C}$ in incubator with $5 \% \mathrm{CO}_{2}$. Wells without cells were used as controls, doxorrubicine as positive control $(36.79 \mu \mathrm{M})$ and dimethyl sulfoxide (DMSO 1\%) as vehicle control. After $24 \mathrm{~h}$ of incubation cells adhesion and growth were observed. Then, the medium was discarded and treatments, controls and DMEM without fetal bovine serum were added in each well. After $24 \mathrm{~h}$ of incubation, the cells were fixed with trichloroacetic acid $(100 \mu \mathrm{L} /$ well $)$ and placed under refrigeration for 1 $\mathrm{h}$ at $4{ }^{\circ} \mathrm{C}$. TCA was removed and plates were washed in low-flow of water three times and dried. Following, plates were stained for $20 \mathrm{~min}$ at room temperature with SRB $0.4 \%$ (50 $\mu \mathrm{L} /$ well). In mildly acidic conditions the colorant binds to basic amino acid residues in fixed cells. This reaction provides an estimate of the total protein mass. The plates were washed with $1 \%$ acetic acid solution and dried at room temperature. The unbound dye was removed after washing, the dyestuff bound to the protein was solubilized in a basic medium (Tris base, $10 \mathrm{mM}$, pH $10.5)$ to determine the optical density in a plate reader at $570 \mathrm{~nm}$. The colorimetric evaluation gives an estimate of total protein mass. The assay was conducted as described in Skehan et al. (1990) with modifications (Voigt, 2005). Cellular concentration used was $1.4 \times 10^{4}$ cells $/ \mathrm{mL}$.

We calculated the average absorbance of the negative control (MAbsNC) and vehicle (MabsVC), for each concentration of the tested substances (MabsT) and positive control (MabsPC). The percentage of living cells was given by:

$\%$ survival $=[($ MAbsT - MAbsNC $) /($ MAbsVC - MAbsNC $)]$ x 100

\section{Induction of quinone reductase assay}

To evaluate the carvones as inducers of quinone reductase, $10^{4}$ cells $/ \mathrm{mL}$ of mouse Hepac $1 \mathrm{c} 7$ cells were seeded in two sterile 96 wells microplates. In one plate (Plate 1), the cytotoxicity assay was carried out using crystal violet dye and in a second plate (Plate 2), the quinone reductase assay (NQO1) was performed. After $24 \mathrm{~h}$ of pre-incubation, the medium was replaced by $190 \mu \mathrm{L}$ of fresh culture medium and $10 \mu \mathrm{L}$ of test compounds, $4^{\prime}$-bromoflavone $(0.01 \mu \mathrm{M})$ or DMSO (vehicle control). NQO1 activity was assessed after $48 \mathrm{~h}$ of cell exposure using 3-(4,5-dime-tylthiazo-2-yl)-2,5diphenyltetrazolium bromide (MTT) reduction to blue formazan based on NADPH-dependent menadiol system. Plate 1: after $48 \mathrm{~h}$, the medium was removed and $100 \mu \mathrm{L}$ of $0.2 \%$ crystal violet solution in $2 \%$ ethanol was added. Subsequently, $200 \mu \mathrm{L}$ of SDS $0.5 \%$ in $50 \%$ ethanol were added. The absorbance was determined in a microplate reader at $590 \mathrm{~nm}$ (Power Wave 200 Microplate Scanning, Bio-Tek Instrument $\left.{ }^{\mathbb{\circledR}}\right)$. Plate 2: medium was removed and $50 \mu \mathrm{L}$ of $0.8 \%$ solution of digitonin in 2 mM EDTA ( $\mathrm{pH}$ 7.8) was added. The plate was incubated at $37^{\circ} \mathrm{C}$ for 10 min (mild agitation). Finally, $200 \mu \mathrm{L}$ of the following reactional mixture was added to the wells: water $-28 \mathrm{~mL}$; Tris-HCl (0.5 M, pH 7.4) - $1.5 \mathrm{~mL}$; tween 20 (1,5\%) $-0.2 \mathrm{~mL}$; FAD $(7.5 \mathrm{mM})-20 \mu \mathrm{L}$; glucose-6-phosphate $(150 \mathrm{mM})-0.2 \mathrm{~mL}$; NADP $(50 \mathrm{mM})-18.0 \mu \mathrm{L}$; albumin bovine serum - $20 \mathrm{mg}$; MTT - $9.0 \mathrm{mg}$; glucose-6-phosphate dehydrogenase $-60 \mathrm{U}$; menadione $(50 \mathrm{mM})-30 \mu \mathrm{L}$. The microplate was stirred until the blue color began to appear. The plates were placed in spectrophotometer and measured at $590 \mathrm{~nm}$ (Scanning Microplate Power Wave 200, Bio-Tek Instrument $^{\circledR}$ ) (Prochaska et al., 1988; Fahey et al., 2004).

NQO1 induction ratio (IR) was represented by specific enzyme activity of cells treated compared to control (DMSO 0.5\%). Compounds were considered active if IR > 2.0. 4' -bromoflavone, a potent NQO1 inducer, was used as positive control for the assay.

\section{Statistical analysis}

One-way analysis of variance (ANOVA) with Tukey's post-test was employed for the statistical analysis for cytotoxicity and chemoprevention results. Data were expressed as the mean $\pm \mathrm{SD}$. 


\section{RESULTS AND DISCUSSION}

\section{Antimicrobial assays}

Compounds C- and HC- only presented antibacterial activity against $S$. aureus at the highest concentration (MIC/MBC: $2.5 \mathrm{mg} / \mathrm{mL}$ ) (Table 1). $\mathrm{C}+, \mathrm{HC}+$ and $\mathrm{EP}$ did not show antibacterial activity. Data from literature showed activity of EP against $S$. aureus using a diffusion method in plates with solid medium (Arruda et al., 2006). Also from literature, $\mathrm{C}$ - and $\mathrm{C}+$ inhibited the growth of E. coli at concentrations of $9.6 \mathrm{mg} / \mathrm{mL}$ (Naigre et al., 1996 ) and $1.5 \mathrm{mg} / \mathrm{mL}$ (MIC) (Helander et al., 1998), respectively. All these literature data differ from results found in our study.

Table I shows the results of MIC for antifungal activity and MFC. Carvones presented weak activity against $C$. tropicalis with values of MIC/MFC of 2.5 $\mathrm{mg} / \mathrm{mL}$ and low inhibitory action against $C$. parapsilosis was also observed (MFC: $1.25 \mathrm{mg} / \mathrm{mL}$ ). C+ presented intermediate activity to C. Krusei $(0.625 \mathrm{mg} / \mathrm{mL})$. Carvones presented activity against $C$. albicans in this study, $\mathrm{C}+$ and $\mathrm{C}$ - were the most active compounds with $\mathrm{MIC} / \mathrm{MFC}$ values of 0.312 and $0.625 \mathrm{mg} / \mathrm{mL}$, respectively. Scientific literature reports that essential oils rich in $\mathrm{C}+$ inhibited the growth of this fungus (Jirovetz et al., 2003) and that carvone inhibited the transformation of C. albicans to its pathogenic form (Mcgeady, Wansley, Logan, 2002). Similarly to carvone and its derivatives, several monoterpenes also showed activity against $C$. albicans, including linalool, citral, citronellol, thymol, eugenol and carvacrol (Zore et al., 2001; Alvarez et al., 2012). All samples inhibited C. krusei and EP and C+ were the most active compounds against this yeast (MIC/ MFC: $0.625 \mathrm{mg} / \mathrm{mL}$ ).

\section{Cytotoxicity assay}

All samples presented low cytotoxicity in the cell lines tested at the concentrations of 0.62 to $50.00 \mu \mathrm{g} / \mathrm{mL}$ and did not reach $\mathrm{IC}_{50}$ or $\mathrm{IC}_{20}$ values (Figure 2). In vitro assays have been used to evaluate toxicity, determine activity and mechanism of action of natural antitumor products (Nagle et al., 2004). Despite carvone and its derivatives did not show cytotoxicity in this study, previous studies showed cytotoxic activity against prostate and breast cancer cell lines, P-815 (murine mastocytoma), K-562 (human chronic myeloid leukemia), CEM (acute lymphoblastoid leukemia T) and MCF-7 (human breast adenocarcinoma) (Stammati et al., 1999; Chen et al., 2006; Jaafari et al., 2012). Natural carvones are present in low concentrations in food and have applications in industry and agriculture, increasing the human exposure to these compounds (Carvalho, Fonseca, 2006). The low toxicity observed in this study suggests safety in the use of carvones.

\section{Quinone reductase assay}

Three independent experiments were performed to evaluate the carvone and derivatives ability to induce quinone reductase enzyme. The cell strain used was Hepa c1c7 and 4'-bromoflavone was used as positive control. Carvones did not show induction of quinone reductase at tested concentrations (Figure 3 ). The percentage of living cells by crystal violet assay also demonstrated that these compounds did not present cytotoxic activity.

\section{CONCLUSIONS}

Plants' secondary metabolites are an important source to development of new drugs. This study evaluated

TABLE I - Determination of minimum inhibitory concentration (MIC) and minimum bactericidal concentration (MBC) of carvones against $\mathrm{S}$. aureus and $\mathrm{E}$. coli

\begin{tabular}{lccccccccccc}
\hline \multirow{2}{*}{ Compounds } & S. aureus & E. coli & \multicolumn{2}{c}{ C. parapsilosis } & \multicolumn{2}{c}{ C. tropicalis } & \multicolumn{2}{c}{ C. krusei } & \multicolumn{2}{c}{ C. albicans } \\
\cline { 2 - 12 } & $\begin{array}{c}\text { MIC/MBC } \\
(\mathbf{m g} / \mathbf{m L})\end{array}$ & $\begin{array}{c}\text { MIC/MBC } \\
(\mathbf{m g} / \mathbf{m L})\end{array}$ & MIC & MFC & MIC & MFC & MIC & MFC & MIC & MFC \\
\hline C+ & $>2.500$ & $>2.500$ & 1.250 & 1.250 & 2.500 & 2.500 & 0.625 & 0.625 & 0.312 & 0.312 \\
C- & $>2.500$ & 2.500 & - & - & 2.500 & 2.500 & 1.250 & 1.250 & 0.625 & 0.625 \\
HC+ & $>2.500$ & $>2.500$ & 1.250 & 1.250 & 2.500 & 2.500 & 1.250 & 1.250 & 1.250 & 1.250 \\
HC- & $>2.500$ & 2.500 & 1.250 & 1.250 & 2.500 & 2.500 & 2.500 & 2.500 & 1.250 & 1.250 \\
EP & $>2.500$ & $>2.500$ & 0.625 & 1.250 & 2.500 & 2.500 & 0.625 & 0.625 & 1.250 & 1.250 \\
Ampicillin & $3,91 \pm 1,56$ & 31,25 & & & & & & & & \\
Amphotericin B & & & 0.500 & 2.000 & 0.100 & 4.000 & 1.000 & 4.000 & 0.500 & 2.000 \\
\hline
\end{tabular}



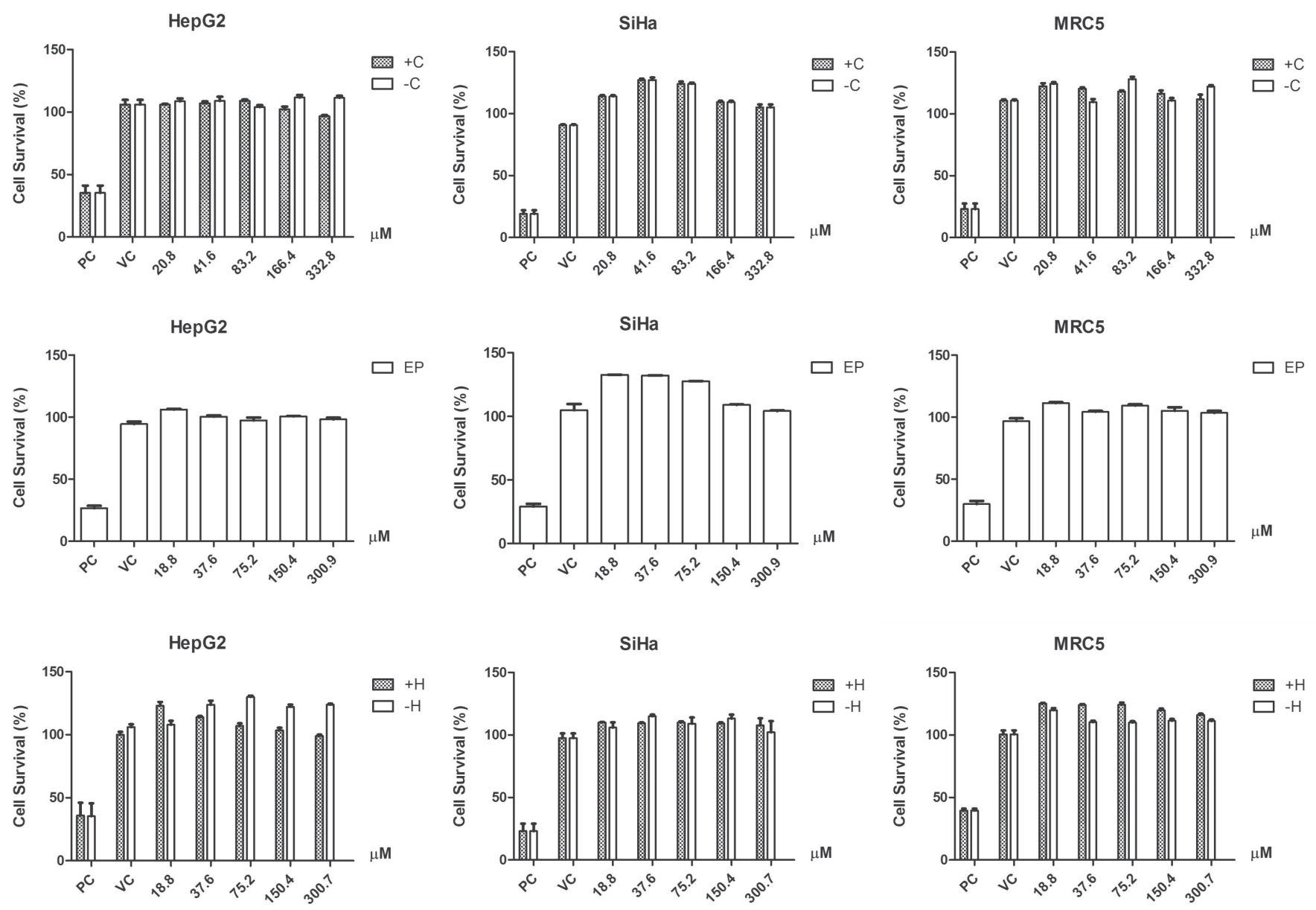

FIGURE 2 - Determination of cell viability (\%) in HepG2, SiHa and MRC-5 for (4S)-(+)-carvone and (4R)-(-)-carvone (C- and $\mathrm{C}+),(+)$-hydroxydihydrocarvone and (-)-hydroxydihydrocarvone ( $\mathrm{HC}+$ and $\mathrm{HC}$-) and $\alpha, \beta$-epoxy-carvone (EP); three independent experiments (mean \pm standard deviation). PC: positive control; VC: vehicle control. Statistical analysis: One-way ANOVA, posttest Tukey. $\mathrm{P}<0.001$.

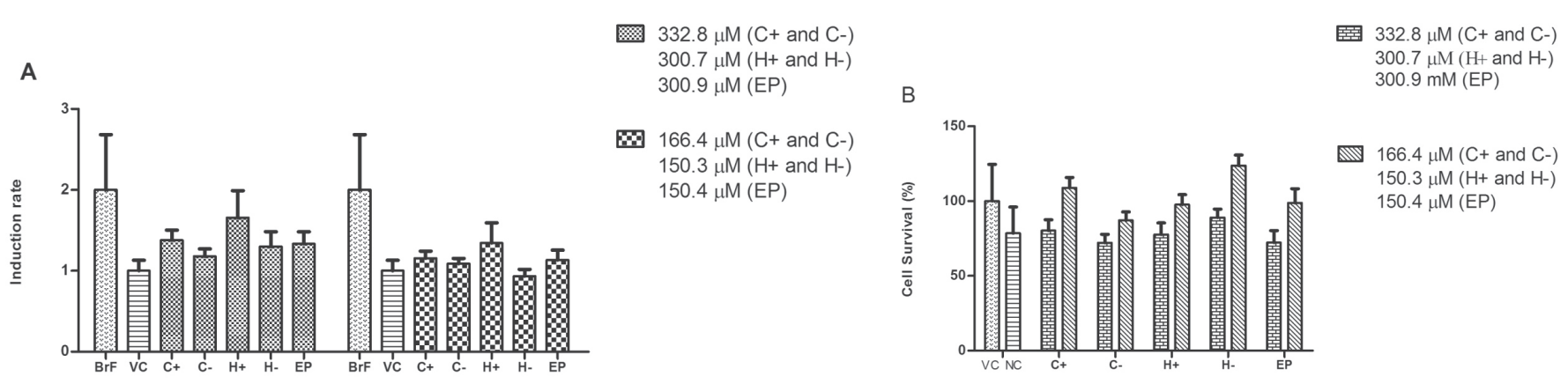

FIGURE 3 - (A)-induced enzyme QR (mean \pm standard deviation) in Hepa c1c7. Positive control: BNF. (B)-cell viability (\%) evaluated by crystal violet assay after treatment during $48 \mathrm{~h}$. Statistical analysis: oneway ANOVA, post-test Tukey.

the activity of carvone and its derivatives against strains of bacteria and fungi, the cytotoxicity in human cells and the inhibition of quinone reductase in murine carcinoma cells. As conclusions, $\mathrm{C}$ - and $\mathrm{HC}$ - showed low activity against $E$. coli. However, EP, $\mathrm{C}+$ and $\mathrm{HC}+$ did not inhibit the growth of the bacteria strains tested. Compounds presented weak antifungal activity against $C$. tropicalis and C. parapsilosis. $\mathrm{EP}$ and $\mathrm{C}+$ showed moderate activity against $C$. krusei similar to $\mathrm{C}+$ and $\mathrm{C}$ - against $C$. albicans. All tested samples demonstrated fungistatic and fungicidal activity against 
Candida yeasts and the most significant result was found with $\mathrm{C}+, \mathrm{C}$ - and $\mathrm{EP}$. These results suggest the potential use of carvones and its derivatives as antifungal agents against Candida yeasts. In citotoxicity SRB assay none of the compounds showed activity in HepG2, SiHa and MRC5 cell lines and also did not inhibit the enzyme quinone reductase. The absence of cytotoxicity in both cancer and normal cell lines indicates the safe use of these compounds.

\section{ACKNOWLEDGMENTS}

Authors are grateful to Coordenação de Aperfeiçoamento de Pessoal de Nível Superior (CAPES) and to Conselho Nacional de Desenvolvimento Cientifico e Tecnológico (CNPq). Scientific Support and Development program of School of Pharmaceuticals Sciences (UNESP)

\section{REFERENCES}

Álvarez SL, Cortadib A, Juárezc MA, Petenattid E, Tomie F, Casanovae J, Van Barenf CM, Zacchinog S, et al. (-)-5,6-Dehydrocamphor from the antifungal essential oil of Zuccagnia punctate. Phytochem Lett. 2012;5(1):194-199.

Arruda TA, Antunes RMP, Catão RMR, Lima EO, De Sousa DP, Nunes XP, et al. Preliminary study of the antimicrobial activity of Mentha $\mathrm{x}$ villosa Hudson essential oil, rotundifolone and its analogues. Braz J Pharmacog. 2006;16(3):307-311.

Bakkali F, Averbeck S, Averbeck D, Idaomar M. Biological effects of essential oils - a review. Food Chem Toxicol. 2008;46(2):446-475.

Carvalho CCR, Fonseca MR. Carvone: why and how should one bother to produce this terpene. Food Chem. 2006;95(3):413-422.

Chen J, Lu M, Jing Y, Dong J. The synthesis of 1-carvone and limonene derivatives with increased antiproliferative effect and activation of erk pathway in prostate cancer cells. Bioorg Med Chem. 2006;14(19):6539-6547.

Clinical and Laboratory Standards Institute. CLSI. Reference method for broth dilution antifungal susceptibility testing on yeasts; approved standard, CLSI document M27-A3, Wayne, Pennsylvania: CLSI; 2008.

Clinical and Laboratory Standards Institute. CLSI. Methods for dilution antimicrobial susceptibility tests for bacteria that grow aerobically; approved standard, CLSI document M7-A9, Wayne, Pennsylvania: CLSI; 2012.
De Almeida RN, De Sousa DP, Nóbrega FFF, Claudino FD, Araújo DAM, Leite JR, et al. Anticonvulsant effect of a natural compound $\alpha, \beta$-epoxy-carvone and its action on the nerve excitability. Neurosci Lett. 2008;443(1):51-55.

De Sousa DP, Oliveira SF, Almeida RN. Evaluation of the central activity of hydroxydihydrocarvone. Neurosci Lett. 2006;29(4):811-812.

De Sousa DP, Nobrega FF, De Almeida RN. Influence of the (r)-(-)- and (s)-(+)-carvone in the central nervous system: a comparative study. Chirality. 2007a;19(4):264-268.

De Sousa DP, Nobrega FF, De Almeida RN, Claudino FS, Mattei R, Leite JR. Pharmacological effects of the monoterpene alpha, beta-epoxy-carvone in mice. Braz J Pharmacog. 2007b;17(2):170-175.

De Sousa DP, Camargo EA, Oliveira FS, De Almeida RN. Antiinflammatory activity of hydroxydihydrocarvone. Zeitschrift Naturforsch C: J Biosci. 2010;65(9/10):543-550.

De Sousa DP. Bioactive essential oils and cancer. 1st ed. New York, USA: Springer International Publishing; 2015. p. 292.

Fahey JW, Dinkova-Kostova AT, Stephenson KK, Talalay P. The "prochaska" microtiter plate bioassay for inducers of nqo1. Meth Enzimol. 2004;383:243-258.

Freire CMM, Costa M. Effects of seasonal variation on the central nervous system activity of ocimum gratissimum 1 . essential oil. J Ethnopharmacol. 2006;105(1-2):161-166.

Helander IM, Alakomi HL, Latva-Kala K, Mattila-Sandholm T, Pol I, Smid EJ, et al. Characterization of the action of selected essential oil components on gram-negative bacteria. J Agric Food Chem. 1998;49(9):3590-3595.

Iacobellis NS, Cantore PL, Capasso F, Senatore F. Antibacterial activity of cuminum cyminum 1 . and carum carvi 1 . essential oils. J Agric Food Chem. 2005;53(1):57-61.

Jaafari A, Mounir T, Mouse HA, M'bark LA, Aboufatima R, Chait A. Comparative study of the antitumor effect of natural monoterpenes: relationship to cell cycle analysis. Rev Bras Farmacog. 2012;22(3):534-540.

Jirovetz L, Buchbauer G, Shafi PM, Abraham GT. Analysis of the essential oil of the roots of the medicinal plant kaempferia galanga 1. (zingiberaceae) from South-India. Acta Pharma Turc. 2001;43(2):4107-110. 
Kaiser R. New or uncommon volatile components in the most diverse natural scents. J Internat Huiles Essent. 1997;15:17-47.

Klein E, Ohloff G. Der stereochemische verlauf der alkalischen epoxydation von, --ungesättigten carbonylverbindungen der cyclischen monoterpenreihe. Tetrahedron. 1963;19(6):10911099.

Lindquist N, Battiste MA, Whitten WM, Williams NH, Strekowski L. Trans-carvone oxide, a monoterpene epoxide from the fragrance of Catasetum. Phytochem. 1985;24(4):863865 .

Mcgeady DL, Wansley DL, Logan DA. Carvone and perillaldehyde interfere with the serum-induced formation of filamentous structures in Candida albicans at substantially lower concentrations than those causing significant inhibition of growth. J Nat Prod. 2002;65(7):953-955.

Nagle DG, Zhou Y, Mora FD, Mohammed KA, Kim Y. Mechanism targeted discovery of antitumor marine natural products. Curr Med Chem. 2004;11(13):1725-1756.

Naigre R, Kalck P, Rogues C, Roux I, Michel G. Comparison of antimicrobial properties of monoterpenes and their carbonylated products. Planta Med. 1996;62(3):275-277.

Oliveira DR, Leitão GG, Bizzo HR, Lopes D, Alviano DSC, Alviano S, Leitão SG. Chemical and antimicrobial analyses of essential oil of lippia origanoides h.b.k. Food Chem. 2007;101(1):236-240.

Oliveira FS, Silva MVB, Sena MCP, Santos HB, Oliveira KM, Diniz MFFM, et al. Subacute toxicological evaluation of hydroxydihydrocarvone in mice. Pharm Biol. 2009;47(8):690696.

Prochaska HJ, Santamaria AB. Direct measurement of nad(p) h:quinone reductase from cells cultured in microtiter wells: a screening assay for anticarcinogenic enzyme inducers. Anal Biochem. 1988;169(2):328-336.
Raut JS, Shinde RB, Chauhan NM, Karuppayil SM. Terpenoids of plant origin inhibit morphogenesis, adhesion, and biofilm formation by candida albicans. Biofouling: J Bioadhesion Biofilm Res.2013;29(1):87-96.

Salgado PRR, Da Fonsêca DV, Braga RM, De Melo CGF, Andrade LN, De Almeida RN, De Sousa DP. Comparative anticonvulsant study of epoxycarvone stereoisomers. Molecules. 2015;20(11):19660-19673.

Skehan P, Storeng R, Scudiero D, Monges A, Mcmahon J, Vistica Dm et al. New colorimetric cytotoxicity assay for anticancer-drug screening. J Natl Cancer Inst.1990;82(13):11071112 .

Stammati A, Bonsi P, Zucco F, Moezelaar R, Alakomi HL, Wright AV. Toxicity of selected plant volatiles in microbial and mammalian short-term assays. Food Chem Toxicol. 1999;37(8):813-823.

Siqueira BPJ, Menezes CT, Silva JP, De Sousa DP, Batista JS. Antiulcer effect of epoxy-carvone. Braz J Pharm. 2012;22(1):144-149.

Voigt W. Sulforhodamine B assay and chemosensitivity. Methods Mol Med. 2005;110:39-48.

Wagner KH, Elmadfa I. Biological relevance of terpenoids overview focusing on mono-, di- and tetraterpenes. Ann Nutr Metab. 2003;47(3-4):95-106.

Zheng GQ, Kenney PM, Lam LKT. Anethofuran, carvone, and limonene - potential cancer chemopreventive agents from dill weed oil and caraway oil. Planta Med. 1992;58(4):338-341.

Zore GB, Thakre AD, Jadhav S, Karuppayil SM. Terpenoids inhibit Candida albicans growth by affecting membrane integrity and arrest of cell cycle. Phytomedicine. 2011;18(13):1181-90.

Received for publication on $27^{\text {th }}$ September 2016 Accepted for publication on $19^{\text {th }}$ April 2017 